\title{
DYNAMIC AND STEADY-STATE PERFORMANCE OF A SYMMETRICAL ANGLE CONTROLLED DC MOTOR
}

\author{
BY \\ S.S. SHOKRALLA AND M.E. EL-SHIBINY \\ Department of Electrical Engineering, Faculty of Engineering, \\ Menoufiya University, Shebin El-Kom, EGYPT
}

\begin{abstract}
In this paper, a complete modelling and numerical simulation are given for a system consisting of a separately-excited dc motor fed from an AC to DC symetrical angle controlled converter through a Bridge rectifier and a power MOSFET. This work presents a detailed theoretical analysis and experimental results to improve the power factor via this converter. The differential equations describing the system behaviour in the different modes of aperation are given. Both transient and steady-state conditions are obtained by solving these equations numerically. Moreover, the effect of control voltage of the converter on the system performance is investigated. The computed performance is verified experimentally where close agreement between the computed and test results is achieved. The results show that the present modelling and numerical simulation is accurate and convenient to obtin the speed controller parameters for closed loop speed control in order to provide specific response.
\end{abstract}

\author{
LIST OF MAIN SYMBOLS \\ B : Viscous friction coefficient. \\ $\mathrm{C}_{\mathrm{o}}$ : Capacitance of the filter capacitor. \\ f : Supply frequency. \\ $i_{m} \quad$ : Instantaneous armature current. \\ $i_{\text {s }} \quad$ : Instantaneous supply current. \\ $\mathrm{J} \quad$ : Moment of Inertia. \\ $\mathrm{K}_{\mathrm{m}} \quad$ : Back e.m.f. coefficient. \\ $\mathrm{L}_{\mathrm{m} 1} \& \mathrm{r}_{\mathrm{n}}$ : Armature inductance and resistance.
}

Manuscript received from Dr. S.S. SHOKRALLA on : 11/3/2000

Accepted on : $25 / 3 / 2000$

Engineering Research Bulletin, Vol 23,No 2, 2000 Minufiya University, Faculty of Engineering, Shebien El-Kom, Egypt, ISSN 1110-1180 
$\mathrm{L}_{\mathrm{L}} \boldsymbol{\&} \mathbf{r}_{\mathrm{L}}$ : Filter inductance and resistance.

$R_{r} \quad$ : Field resistance.

$T_{L} \quad$ : Load torque.

U : Integrator output.

$\mathrm{v}, \mathrm{V}$ : Instantaneous and peak values of supply voltage.

$V_{c}$ : Control voltage.

$V_{m} \quad$ : Motor voltage.

$\omega \quad$ : Supply angular velocity.

$\omega_{m} \quad$ : Motor angular velocity.

$\tau_{1}, K_{1}:$ Controller parameters.

\section{INTRODUCTION}

The classical solution of $\mathrm{AC}-\mathrm{DC}$ rectification using a full wave diode bridge followed by a bulk capacitor is being disconnected, due to its harmonic current content, which is rich in low-order components [1].

Many studies were reported to develop different circuit configurations to reduce the harmonic contents and improve power factor for static loads [2-6]. Several active schemes have been proposed and analyzed for shaping the line current for single-phase applications [7-9]. A theoretical analysis of cascade buck-boost converter for static resistance-inductance load is presented [10]. A high power factor electronic ballast based on a single power processing stage with constant dc-link voltage is presented [11]. Steady-state behaviour of dc motor supplied from a single-phase rectifier followed by a step-up converter has been investigated [12]. Pulse width modulation control technique using three switches, three-phase dc drive system has been investigaged [13]. The operation of dc motor supplied from AC-to-DC cuk converter has been studied in both transient and steady-state under open and closed loop speed control [14]. In Reference [15], steady-state characteristics is investigated for dc series motor supplied from symmetrical angle control. No attention has been paid to the dynamic performance and speed control of a d.c. motor supplied from single-phase AC-DC symmetrical angle control converter. In this paper, a complete modelling and numerical simulation are obtained for a system consists of a dc seperately excited motor fed from an $\mathrm{AC}$ to DC. symmetrical angle controlled converter through a Bridge rectifier and one MOSFET. The differential equations which describe the system behaviour are impelemented in a simulation program. This program are used to predict steady-state, run-up and transient conditions for the proposed system. The simulation program enables to compute the speed controller parameters for closed-loop operation. 


\section{SYSTEM DESCRIPTION}

Figure (1) shows the schematic diagram of the complete control system for speed control. The system consists of a cascade combination of diode bridge rectifier and symmetrical angle control converter connected to $\mathrm{AC}$ single-phase supply which fed dc separately excited motor. The motor votlage is regulated by regulating the control voltage $\left(V_{c}\right)$ from 0 to maximum value (A) of the timing voltage $\left(\omega_{a}\right)$ as shown in Figure (2). This technique is used to control motor speed. The inductance $L_{L}$ and $C_{0}$ are used as a d.c. filter. The MOSFET type IRFP 450 is fired by an impulse generator. The gate pulses are generated as shown in Figure (2). The parameter values of the designed system are given in Appendix (1),(2).

\section{MODELLING AND MODES OF OPERATIONS}

Figure (3) shows the modes of operation and can be demonstrated as given below:

\subsection{Modelling of the power circuit and motor:}

\section{Mode (1)}

In this mode, the MOSFET is turned ON as shown in Figure (3).

The differential equations describing this mode are written as follows:

$$
\begin{aligned}
\mathbf{L}_{\mathrm{L}}\left(\mathbf{d i} \mathrm{L}_{\mathrm{L}} / \mathbf{d t}\right) & =\mathbf{v}_{\mathrm{s}}-\mathbf{i}_{\mathrm{L}} \mathbf{r}_{\mathrm{L}}-\mathbf{v}_{\mathrm{m}} \\
\mathbf{L}_{\mathrm{m}}\left(\mathbf{d i _ { m }} / \mathbf{d t}\right) & =\mathbf{v}_{\mathrm{m}}-\mathbf{i}_{\mathrm{m}} \mathbf{r}_{\mathrm{m}}-\mathbf{k}_{\mathrm{m}} \omega_{\mathrm{m}} \\
\mathbf{J}\left(\mathbf{d} \omega_{\mathrm{m}} / \mathbf{d t}\right) & =\mathbf{K}_{\mathrm{m}} \cdot \mathbf{i}_{\mathrm{m}}-B \omega_{\mathrm{m}}-\mathbf{T}_{\mathrm{L}} \\
\mathrm{C}_{\mathrm{o}}\left(\mathbf{d} \mathbf{V}_{\mathrm{m}} / \mathbf{d t}\right) & =\left(\mathbf{i}_{\mathrm{L}}-\mathbf{i}_{\mathrm{m}}\right) \\
\mathbf{i}_{\mathrm{s}} & =\mathbf{i}_{\mathrm{L}} \\
\mathbf{v}_{\mathrm{S}} & =\mathrm{V}|\sin \omega t|
\end{aligned}
$$

\section{Mode (2)}

In this mode, the MOSFET is turned OFF as shown Figure (3). The differential equations describing this mode are written as follows:

$$
\begin{aligned}
& L_{m}\left[d i_{m} / d t\right]=v_{m}-r_{m} i_{m}-k_{m} \omega_{m} \\
& J\left[d \omega_{m} / d t\right]=k_{m} i_{m}-B w_{m}-T_{L} \\
& C_{n}\left[d V_{m} / d t\right]=i_{L}-i_{m}
\end{aligned}
$$




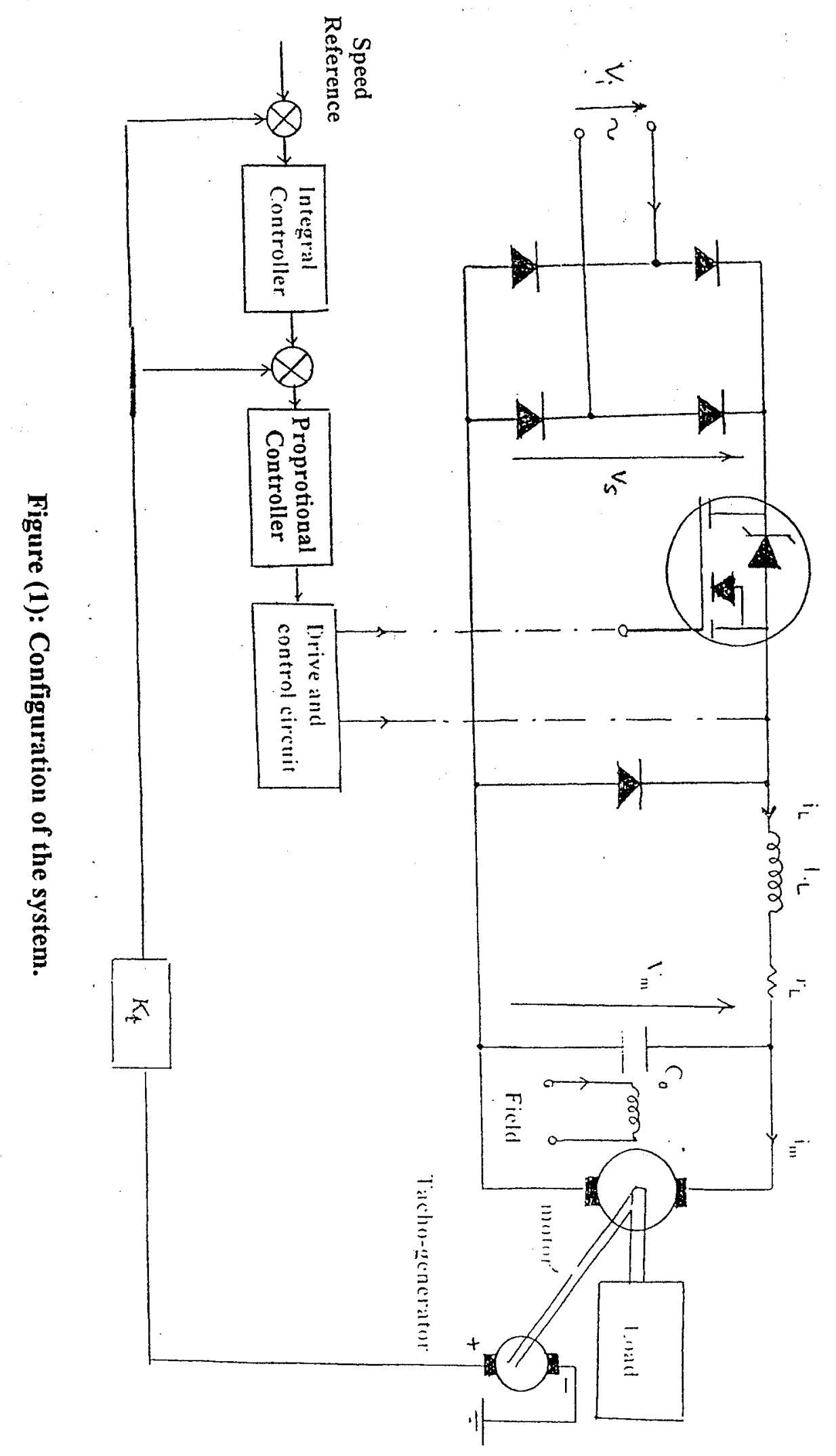



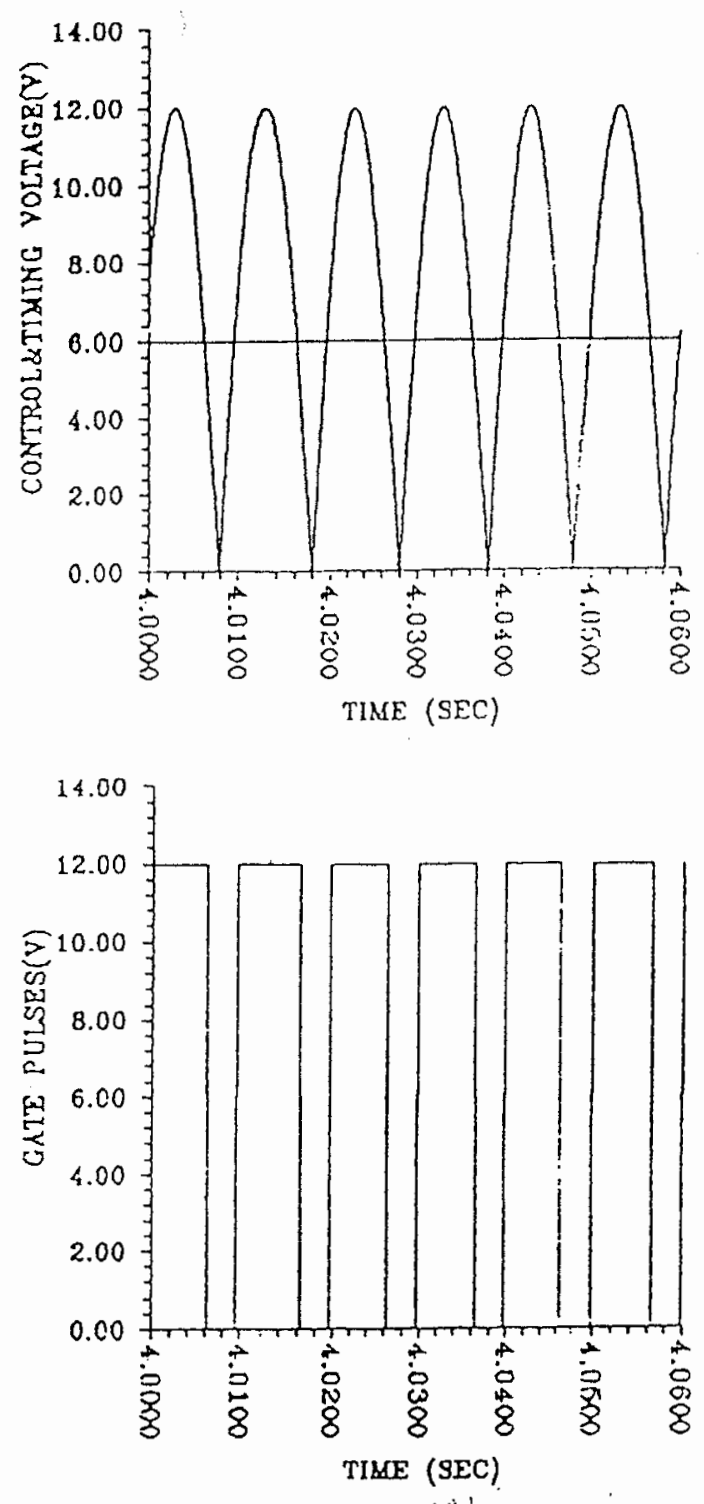

(a) Simulation

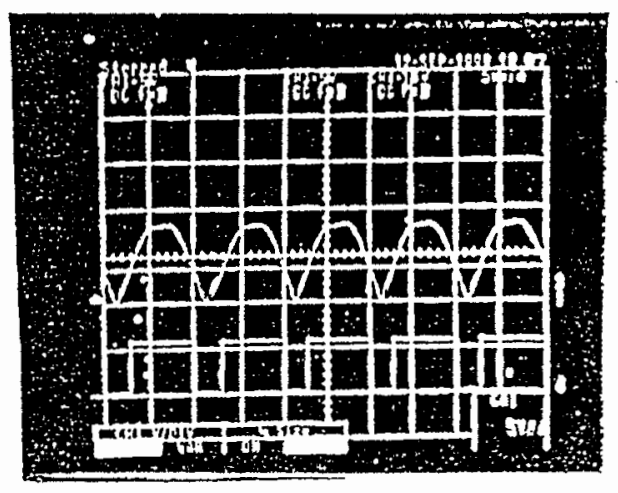

(b) Experimental

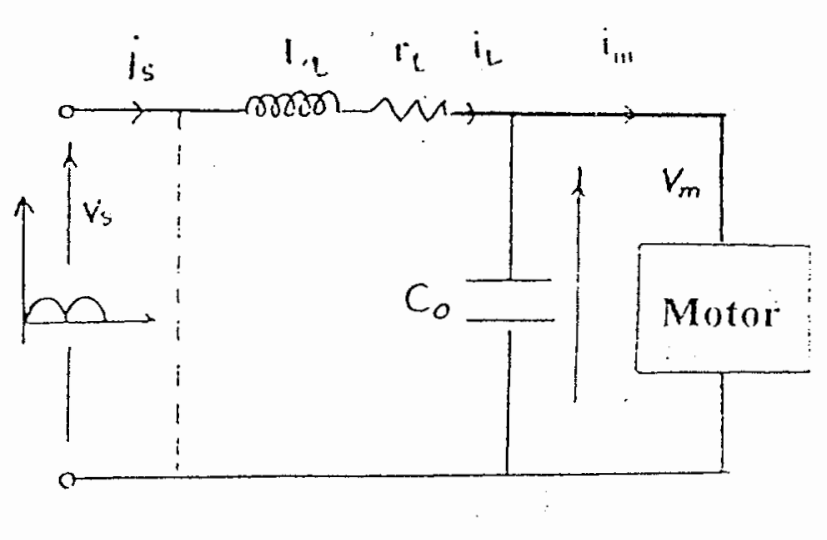

Node (1): MOSFET is ON

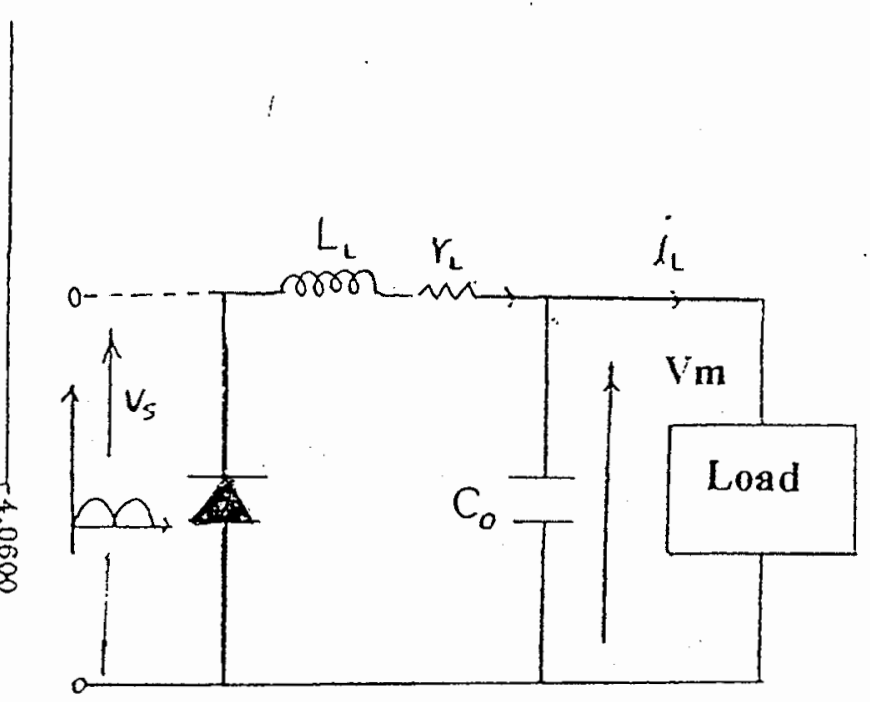

Node (2): MOSFET is OFF

Figure (3): Modes of operation for the system.

Figure (2): Output of pulse generator circuit. 
$L_{L}\left[d i_{L} / d t\right]=-v_{m}-i_{L} r_{L}$

$$
\mathbf{i}_{\mathrm{s}}=\mathbf{0}
$$

\subsection{Modelling of the impulse generator}

From Figure (2) the equation which represents the timing voltage is givin by the following expression:

$$
\omega_{\mathrm{a}}=\mathrm{A} \sin \omega \mathrm{t}
$$

where, $A$ is the maximum voltage signal (12 volt), $\omega$ is the angular velocity and $t$ is the time. The chopping period $T$ is given by:

$$
T=\omega(1 / f)
$$

MOSFET is turned ON when $\quad v_{c}<\omega_{a}$ MOSFET is turned OFF when $\quad v_{c}>\omega_{a}$

\subsection{Power factor calculation}

The total harmonic components of the supply input current $I_{\text {st }}$ is given by:

$$
\mathbf{I}_{\mathrm{st}}=\left(\mathbf{I}_{\mathrm{s}}^{2}-\mathbf{I}_{\mathrm{s1}}{ }^{2}\right)^{0.5}
$$

where, $I_{S}, I_{\mathbf{S 1}}$ are the r.m.s. value of the supply current and fundamental component respectively. The total harmonic distortion factor of the supply current (THDF) is given by:

$$
\text { THDF }=\mathbf{I}_{\mathbf{S t}} / \mathbf{I}_{\mathbf{S I}}
$$

The supply input power factor si given by:

$$
\mathrm{PF}=\text { power factor }=\operatorname{Cos} \phi_{\mathrm{s} 1} /\left[1+\mathrm{THDF}^{2}\right]^{0.5}
$$

\section{EXPERIMENTAL AND SIMULATION RESULTS}

The proposed system is designed and implemented to verity the developed model of this system. The behaviour of this system under transient and steady-state conditions is determined by solving the nonlinear differential equations using the fourth order Runge-Kutta method. The instantenous and r.m.s. values of supply input current and voltage, motor current and voltage and motor speed are obtained from the proposed numerical simulation of this system. The open loop and closed loop behaviour of this system have been studied. 


\subsection{Steady-State Characteristics}

The given steady-state characteristics include both the effect of varying control voltage $\left(V_{c}\right)$ and samples of waveforms as follows:

\subsection{Effect of Control Voltage}

Figure (4) shows the effect of varying the control voltage on the motor current, motor voltage, motor speed and supply input power factor for $\mathbf{0 . 5}$ and 0.75 full load torque. It is noted that increasing the control voltage results in an decrease in motor voltage, current and speed. Also, it is noted that the input power factor varies in an acceptable range for such systems compared with thyristor fully controlled rectifier systems. [15-16)].

Figure (5) shows samples of the steady-state waveforms for control voltage $\left(V_{c}\right)$ of 6 volt and half load torque. It is noticed that the agreement between the measured and computed values is acceptable for steady-state characteristics and waveforms.

\subsection{Run-Up Behaviour}

Figure (6) shows the waveforms of supply voltage, supply current, motor voltage, motor current and motor speed when the motor is started with a load of half the rated torque at control voltage $=6$ volt. It is noted that the supply current at starting is about 1.5 of the steady-state value, while the run-up period is about 0.5 second.

\subsection{Load Torque Disturbance}

Figure (7) shows the response of motor current and speed for a change in load torque from 0.5 to 0.75 of the rated value. Figure (8) shows the response of the same quantities for a change in load torque from 0.75 to 0.5 of the rated value. The control voltage for load torque disturbances is equal to 6 volt. It is observed that the motor current is increased with increasing the load torque and the motor speed is decreased as shown in Figure (7). The reverse effect is observed in Figure (8).

\subsection{Control Votlage Disturbance}

Figure (9) shows the system response for motor voltage and speed for positive and negative step change in the control voltage from 10 to 7 volt and from 7 to 10 volt with a half full load. The motor voltage and speed are increased with decreasing in control voltage due to increasing the MOSFET ON state. 


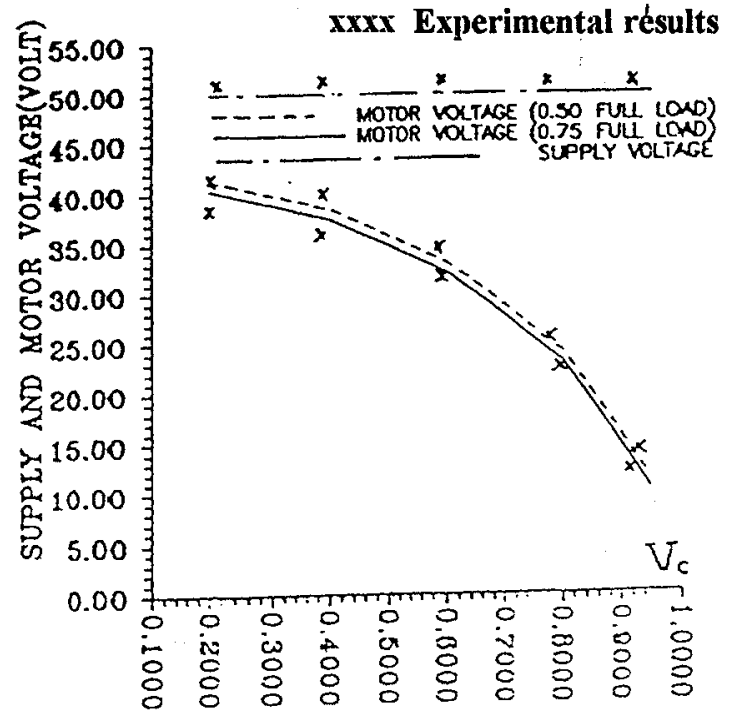

(a) Supply and Motor voltage

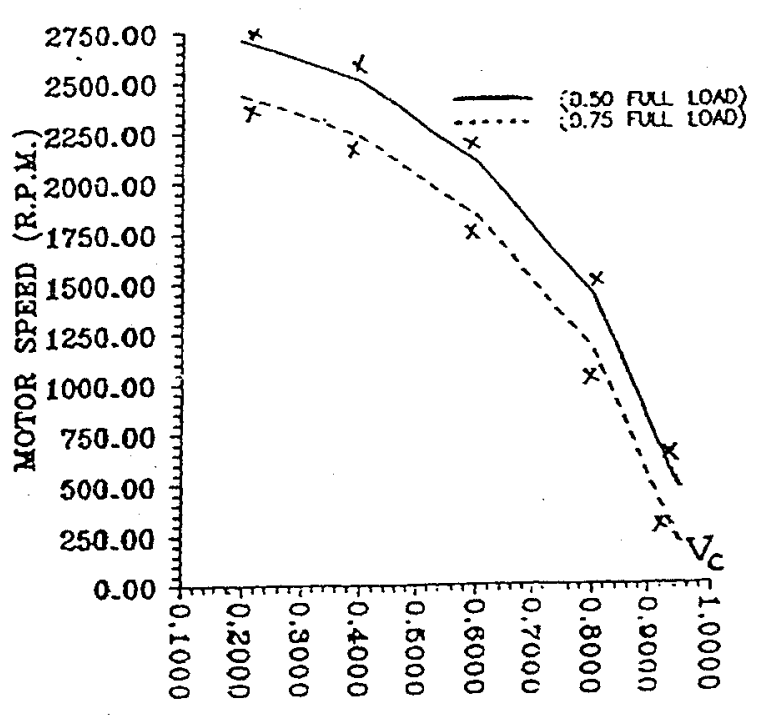

(c) Motor Speed

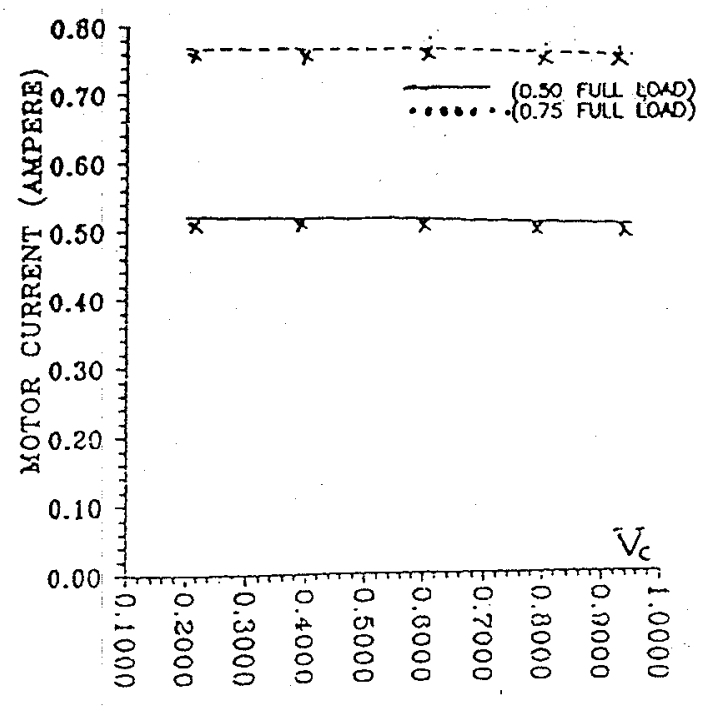

(b) Motor Current.

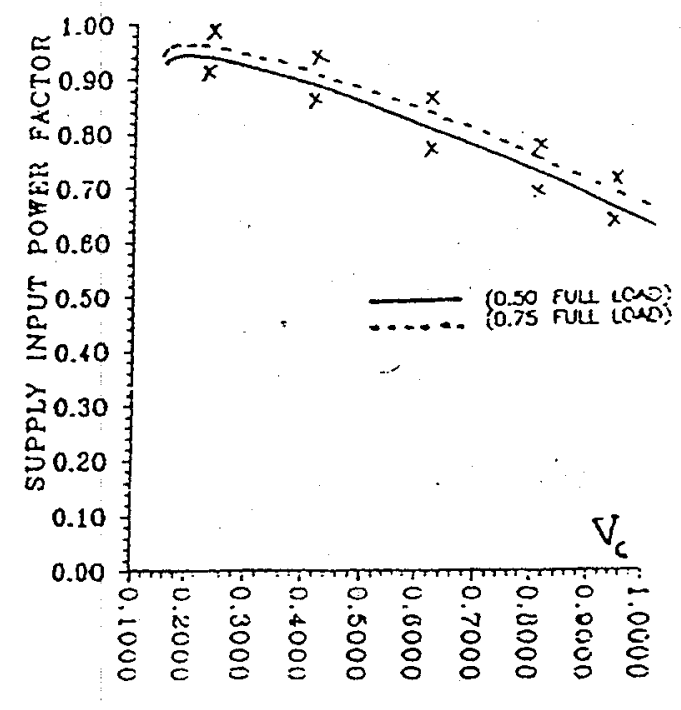

(d) Supply Input Power Factor

Figure (4): Effect of Control Voltage on the Steady-State Characteristics. 

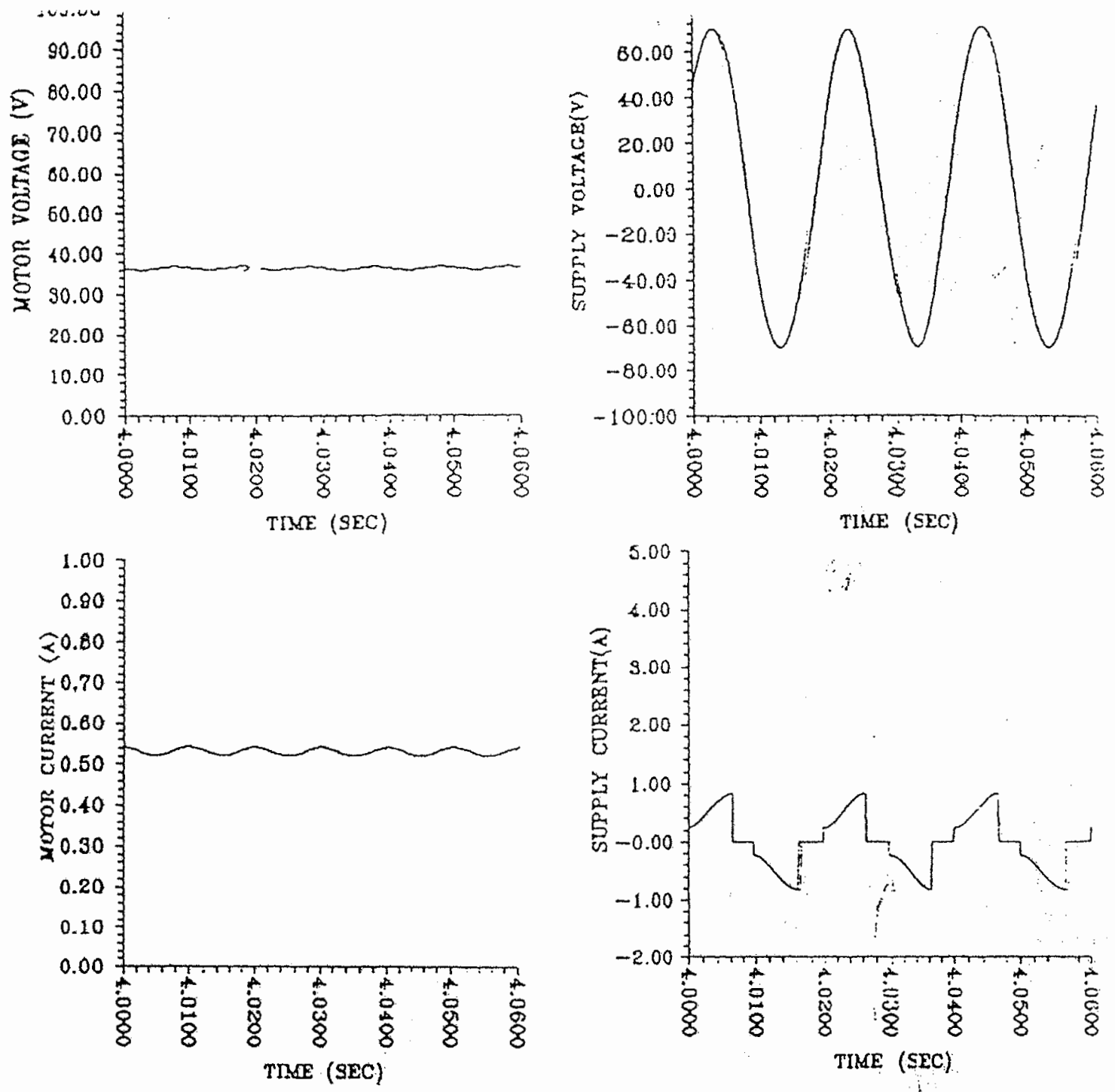

(a) Simulation

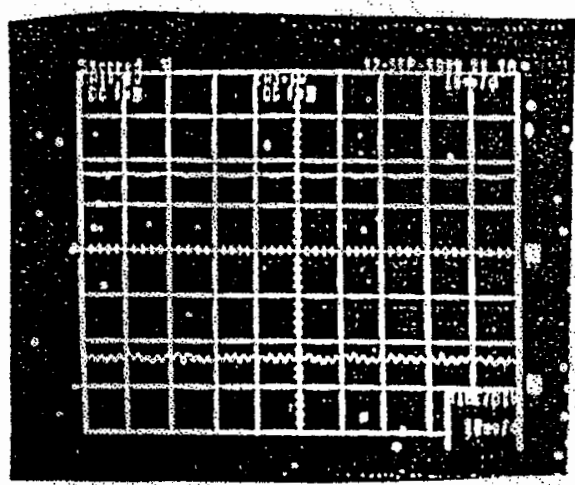

(c) Simultion

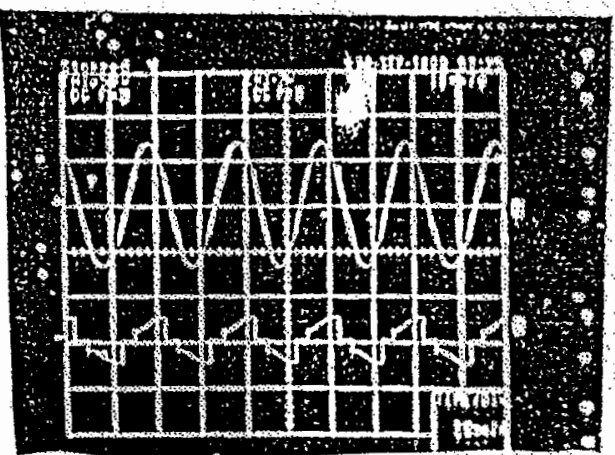

(b) Experimental

(d) Experimental

Figure (5): The steady-state waveforms at half load and $V_{C}=6$ valt. 

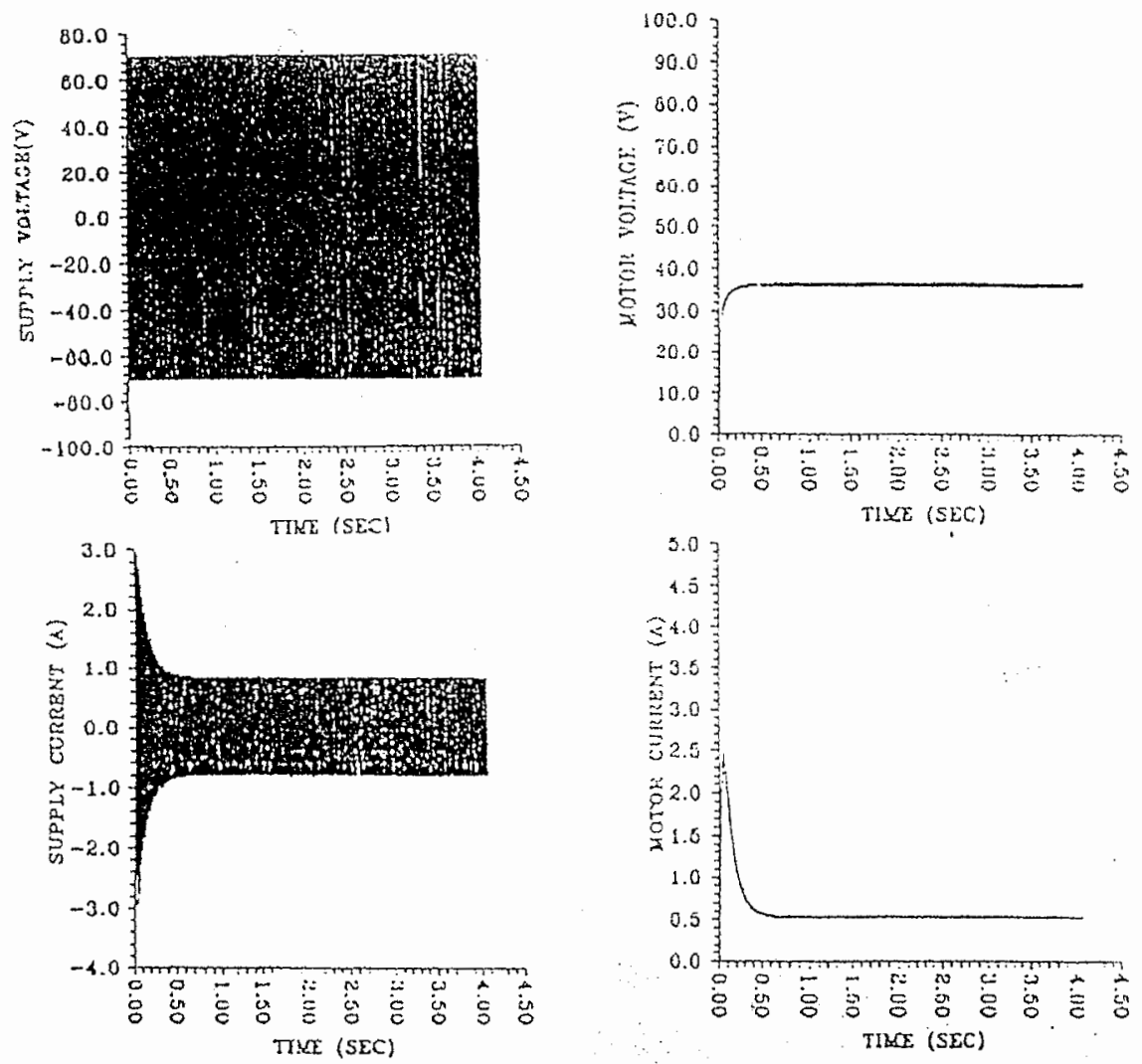

(a) Simulation

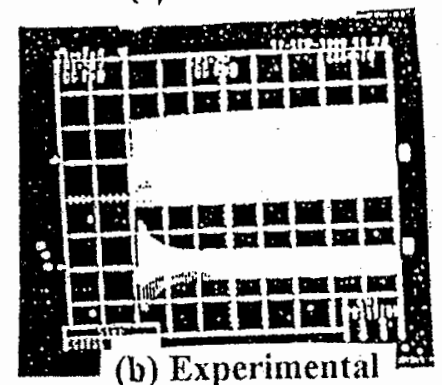

(c) Simultion

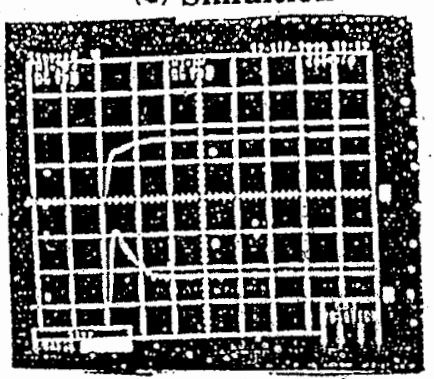

(d)Experimental
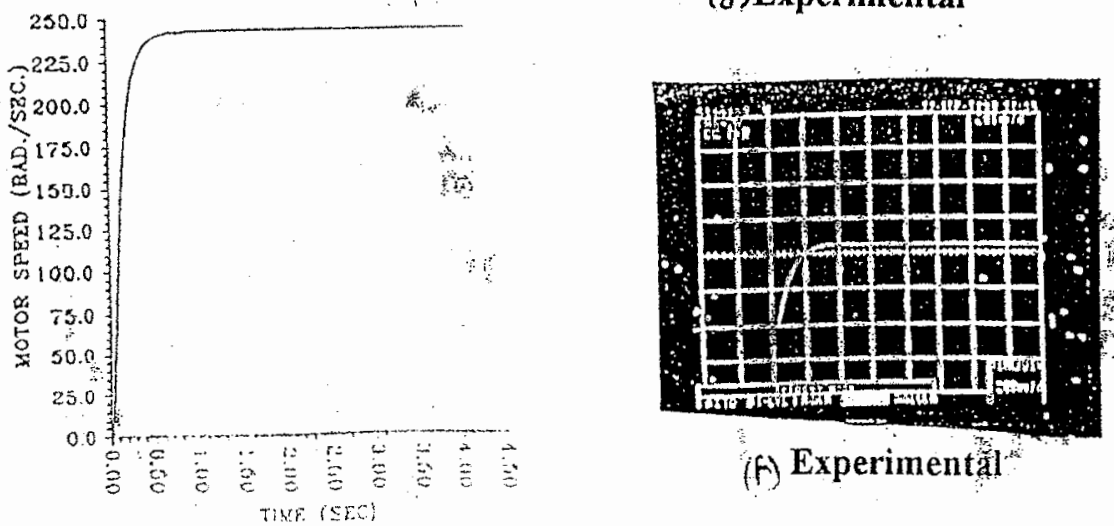

(f) Experimenta

(c) Simultion

Figure (6): Run-ip behaviour for half the rated load torcua and control voltage $=6 \mathrm{Volt}$. 
alysis of large-scale power system by Lyapunov's direct method',IEEETrans.,1984, Vol PAS-103,No1,pp.160-167

8 - Grujic, LJ.T., Ribbens-Pavella, M., and Bouffioux, A.:" Asymptotic stability of large-scale systems with application to power systems. Part 2: transient analysis', Int. J. Electr. Power Energy Syst., 1979 , Vol.1, No.3, pp. 158-165

9 - Jocic, LJ.B., and Ribbens-Pavella, M., and Siljak, D.D.:' Multimachine power systems : stability, decomposition, and aggregation', IEEE Trans.,1978, AC-23, No.2, pp. 325-332

10 - Araki, M., Metwally, M.M., and Siljak, D.D.:' Generalized decompositions for transient stability analysis of multimachine power systems', Proc. Joint Automatic Control Conf., Califomia, August, 1980, pp. 1-7

11- Mahalanabis, A.K. and Singh,R.:'On the analysis and improvement of the transient stability of multimachine power systems", IEEE Trans.1981,PAS-100,No. 4. pp.1574-1579

12 -Michel, A.N., Nam, B.H., and Vittal, V.: Computer generated Lyapunov functions for interconnected systems: improved results with applications to power syst-ems', IEEE Trans.,1984,CAS-31.No.2,pp. 189-198

13 - Shaaban, H., and Grujic, LJ.: Transient stability analysis of large-scale power systems with speed govemor via vector Lyapunov functions', Proc.IEE, 1985, Vol. 132 ,pt.D,No.2, pp. 45-52

14 - Shaaban, H., and Grujic, LJ.: Improvement of large-scale power systems decomposition-aggregation approach', Int. J .Electr. Power Energy Syst.,1986, Vol. 8,No.4, pp. 211-220

15 - Shaaban, H:' New decomposition-aggregation approach applied to power system with speed govemor', IEE-Proc.-C,1991,Vol.138,No.5,pp. 434-444

16 - Shaaban, H., and Grujic, LJ.,:' Transient stability analysis of power systems via aggregation on subsets', Int.J.Control,1994,Vol.59,No.6,pp.1401-1419

17 - Shaaban, H.,: Transient stability analysis of multimachine power system considering generator flux decay ", Engg. Research Bulletin. Faculty of Engg., Menoufia Univ., Egypt, Vol.22,No.3,1999, pp151-168

18 - Shaaban, H.: New stability approach applied to large-scale power systems with generator flux decay', Alexandria Engineering Journal, Alex. Univer.,Egypt, Vol.37,No.2,1998,pp.53-76

19-Anderson,P.M., and Fouad,A.A.'Power system control and stability',(Book) Iowa State Univ.Press, 1977

20 - Zhou,E.Z,Malik,O.P., and Hope,G.S.:'Theory and method for selection of power system stabilizer location', IEEE Trans. On Energy Conversion, Vol.6,No 4, March, 1991, pp.170-176

21 - Grujic, IJ., and Ribbens-Pavella, M:' Asymptotic stability of large-scale systems with application to power systems. Part 1 : domain estimation', Int. J. Elect. Power Energy Syst., 1979,1, pp. 151-157

\section{APPENDIX}

Table I : The system reduced admittance matrix ( moduli in p.u. and arguments in deg.)

$\left[\begin{array}{l|l|l|l|l}1.68799 & \angle-71.68 & 0.51323 \angle 79.44 & 0.00051 \angle 98.07 & 0.00048 \angle 104.0 \\ 0.00058 \angle 88.92 & 0.00155 \angle 103.64 & 0.73660 \angle 94.39\end{array}\right]$



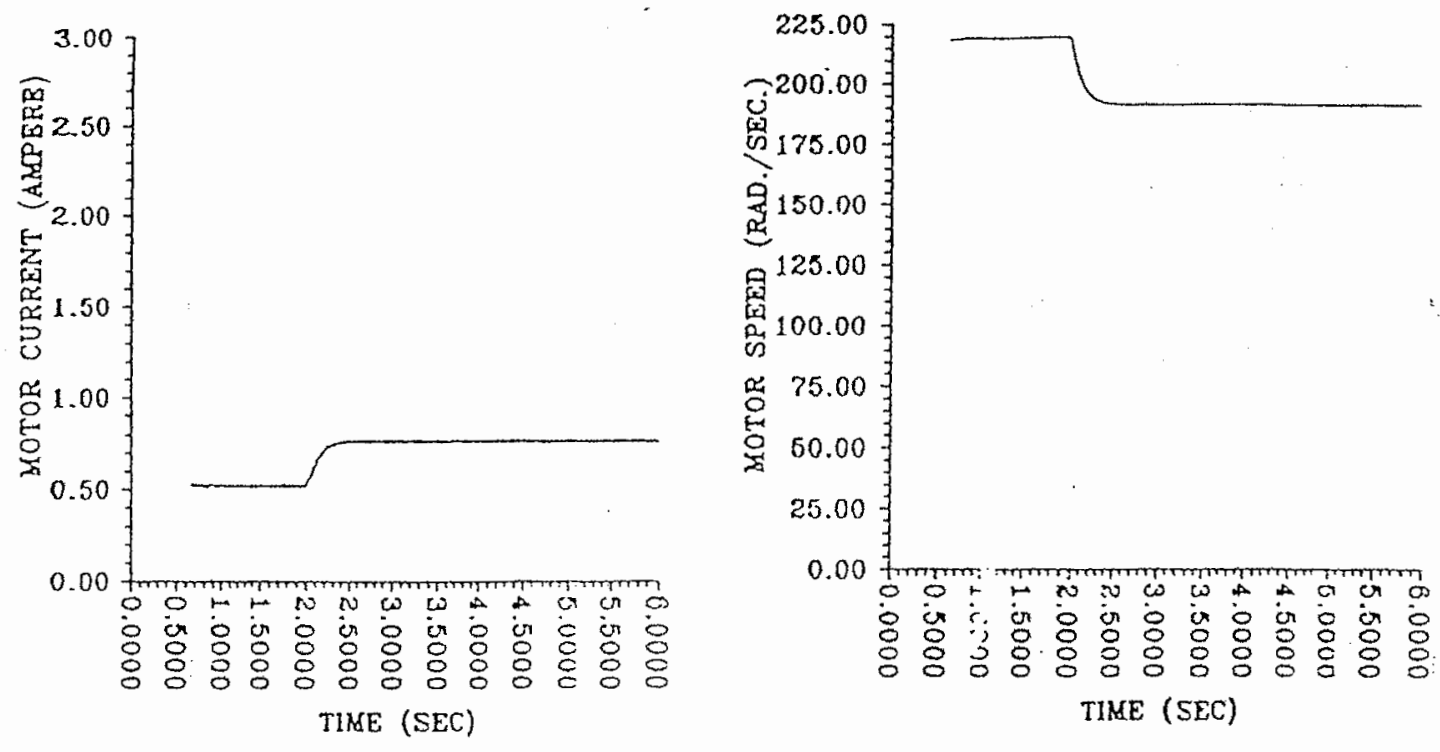

(a) Simultion
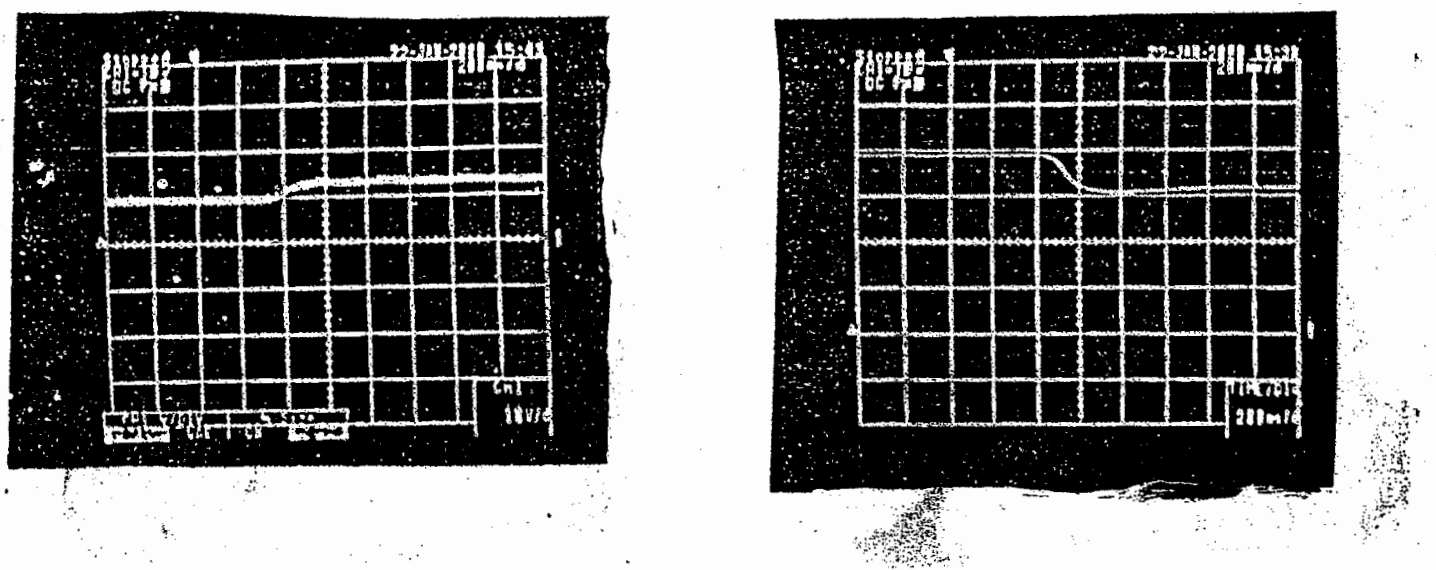

(b) Experimental

Figure (7): Positive change in load torque from $0.5: 0.75$ cf ratad val:a with control voltage $=6 \mathrm{Volt}$. 

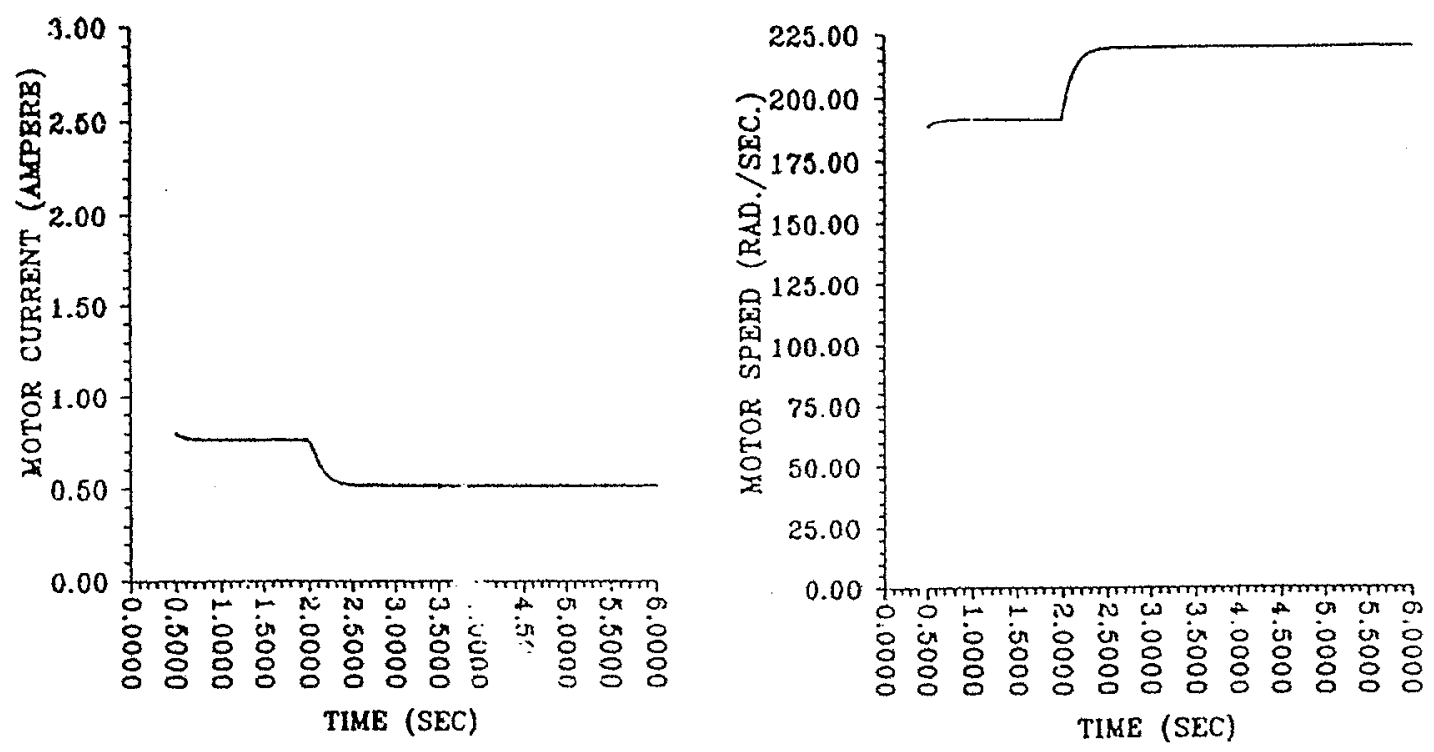

(a) Simulation
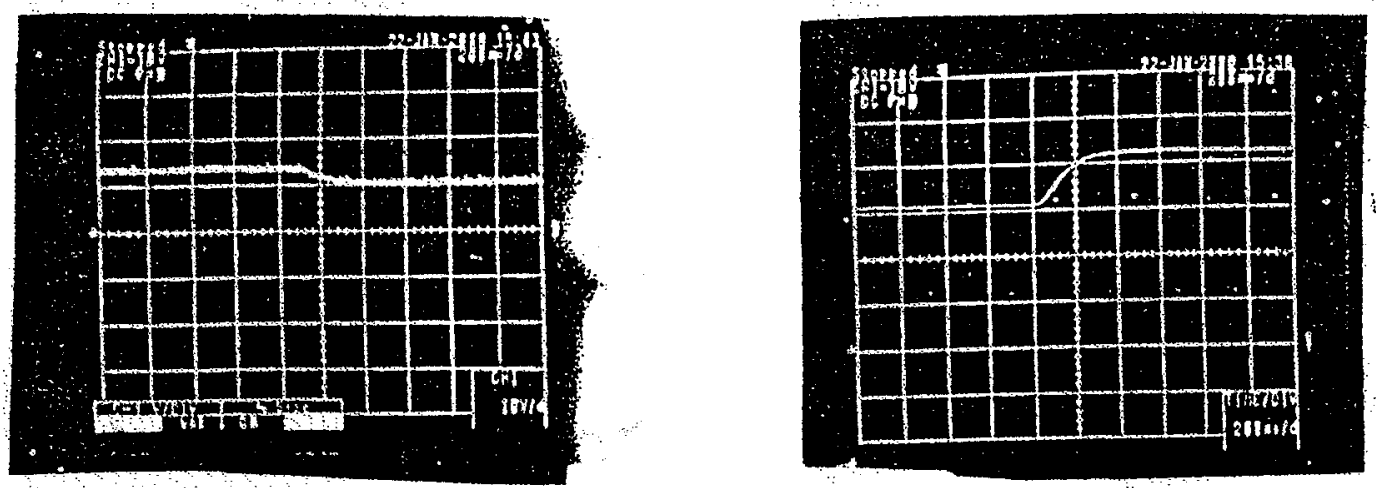

Experimental

Figure (8): Negative change in load torque from $0.75: 0.5$ of rated value with control voltage $=6$ Volt. 


\section{CLOSED LOOP SPEED CONTROL}

The open loop transfer function (T-F) of the speed response with a step change in control voltage for this system is obtained using the proposed numerical simulation. Figure (9) shows the results of the computed and experimental speed response which are obtained by step change of the control voltage from 10 to 7 to 10 volt at half full-load. It is noticed that the transfer function of this system has a form of a first order for wide range of load torque. This is due to the electromenchanical time constant $\left(T_{e m}\right)$ is quite large compared with the electrical time constant [14-17]. The open-loop transfer function for this system may be represented by the following equation:

$$
\mathbf{T} . \mathbf{F}=K /\left(1+\mathbf{T}_{\mathrm{em}} \mathbf{S}\right)
$$

The parameters $K$ and $T_{e m}$ are given in Appendix (3).

Figure (10) illustrates the complete circuit for closed-loop speed control system. Therefore, the overall closed-loop transfer function is given by:

$$
\omega_{m} / V_{\text {Ref }}=K K_{1} /\left(\tau_{1} T_{e m} S^{2}+\tau_{1}\left(1+K K_{1} K_{t}\right) S+K K_{1} K_{t}\right)
$$

The system characteristic equation is:

$$
S^{2}+\left(1+K K_{1} K_{t} / T_{e m}\right) S+\left(K K_{1} K_{t} / \tau_{1} T_{e m}\right)=0
$$

This equation takes the following standard second-order form:

$$
S^{2}+\left(2 \eta \omega_{i n}\right) S+\omega_{n}^{2}=0
$$

Comparing equations (19) and (20) gives the following relations for the controller parameters:

$$
\begin{aligned}
& K_{1}=\left(1 / K K_{t}\right)\left(2 \eta T_{e m}-1\right) \\
& \tau_{1}=\left(1 / \omega^{2}{ }_{m}^{\prime} T_{e m}\right)\left(2 \eta T_{e m}-1\right)
\end{aligned}
$$

The proportional and integral controller parameters $\left(K_{1}\right.$ and $\left.\tau_{1}\right)$ can be calculated by selecting a suitable value for damping ratio $\eta$ according to the allowable maximum overshoot. The controller parameters are given in Appendix (3).

The controller equation is given as follows:

$$
\begin{aligned}
& \tau_{1}(\mathbf{d U} / \mathbf{d t})=\left(V_{\text {ref }}-K_{t} \omega_{m}\right) \\
& V_{C}=K_{1}\left(U-K_{t} \omega_{m}\right)
\end{aligned}
$$



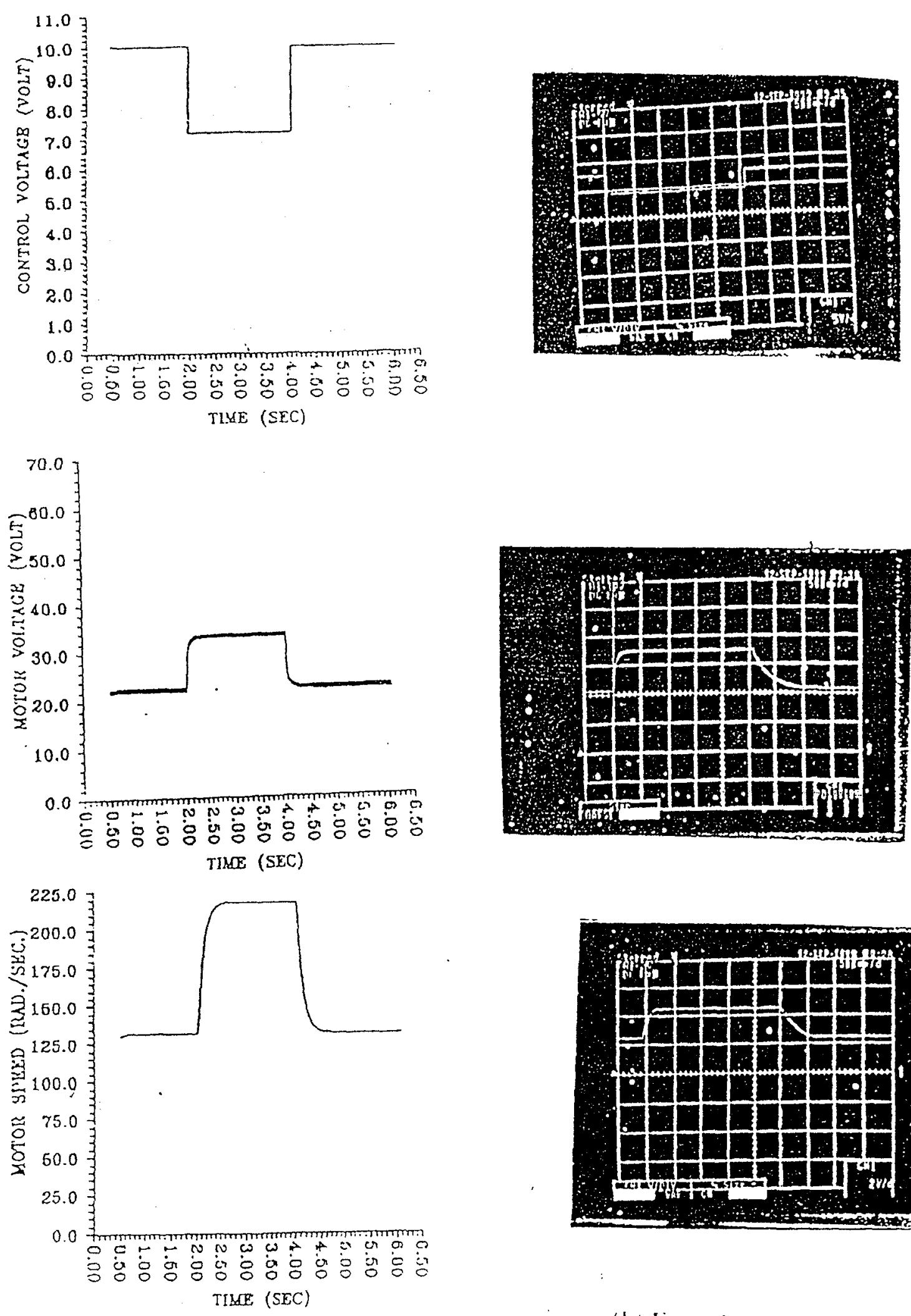

(a) Simmlation

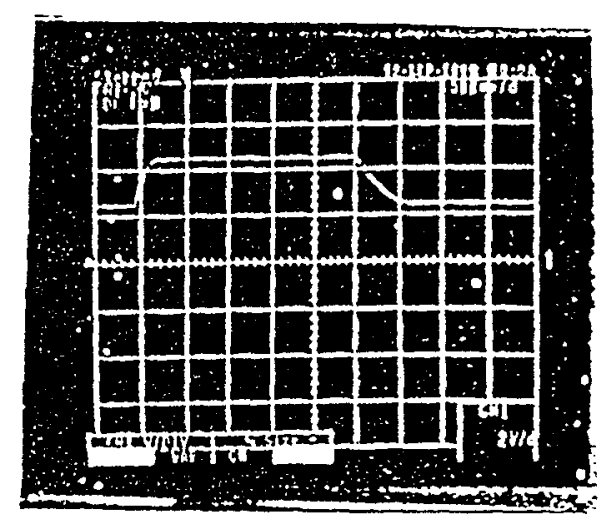

(b) Experimental

Figure (9): Speed and current responses due to positive and negative step change in control voltage with half full-load for open loop system. 
Figure (11) shows the computed and experimental response of motor speed due to step change in the reference voltage at half full load. It is clear that the motor can follow the desired speed reference smoothly.

Figure (12) shows the computed and experimental results of motor speed due to positive and negative change in load torque form 0.5 to 0.6 and from 0.6 to 0.5 full load torque respectively. It is observed that the speed has returned to its initial value after $380 \mathrm{~m} . \mathrm{sec}$. which in turn confirms the validity of the proposed system.

\section{CONCLUSIONS}

In this paper a theoretical and experimental study for steady-state and dynamic performance of a separately-excited d.c. motor fed from a singlephase $A C$ to $D C$ symetrical angle controlled converter through a bridge rectifier and one power MOSFET. The control circuit for this system is simple and has a step down capability. This system is used to achieve an improvement of the supply input power factor. Moreover, the dc motor voltage and current are smooth. The dynamic and steady-state behaviour are predicted using the proposed modelling and numerical simulation. Further, the simulation may be considered as a good tool to predict the suitable proportional integral controller parameters for closed loop speed control. However, the best responses of speed due to load torque and speed reference disturbances are obtained. The motor speed can follow the desired speed reference smoothly and fast with reasonable overshoot. Also, the speed is found to remain constant with load torque changing. The comparison between the simulation and experimental results for open and closed-loop systems have proved close agreement with each other.

\section{APPENDICES}

Appendix (1)

The parameters of the designed system are as follows:

$$
\begin{aligned}
& \mathrm{Vi}_{\max }=71 \text { volt } \\
& L_{L}=0.099 \text { henry } \\
& r_{L}=20 h m, \quad C_{0}=1200 \mu F \\
& \mathrm{~A}=12 \text { volt } \quad, \quad F_{\mathrm{S}}=50 \quad \mathrm{~Hz}
\end{aligned}
$$

\section{Appendix (2)}

The test motor is a separately excited DC motor, 55 volt, 50 watt, 1 ampere, 3000 r.p.m. having the following measured parameters:

$$
\begin{array}{ll}
\mathbf{R}_{\mathrm{a}}=10.5 \mathrm{ohm} \quad, & \mathbf{L}_{\mathrm{a}}=0.06 \mathrm{H} \quad, \\
\mathbf{R}_{\mathrm{r}}=550 \mathrm{ohm} \quad, & \mathbf{B}=0.0001 \mathrm{~N} . \mathrm{m} . /(\mathrm{rad} . / \mathrm{sec} .) \\
\mathbf{K}_{\mathrm{m}}=0.127 \mathrm{volt} /(\mathrm{rad} . / \mathrm{sec}) & \mathbf{J}=0.0012 \quad \mathrm{Kg} \cdot \mathrm{m}^{2} .
\end{array}
$$




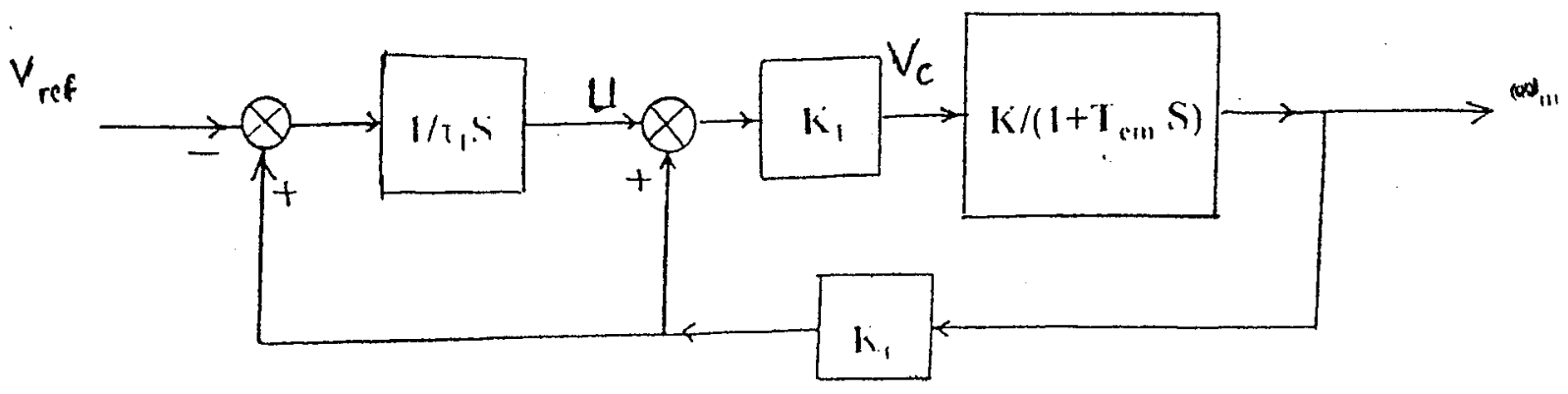

Figure (10): Complete block diagram for closed loop system.
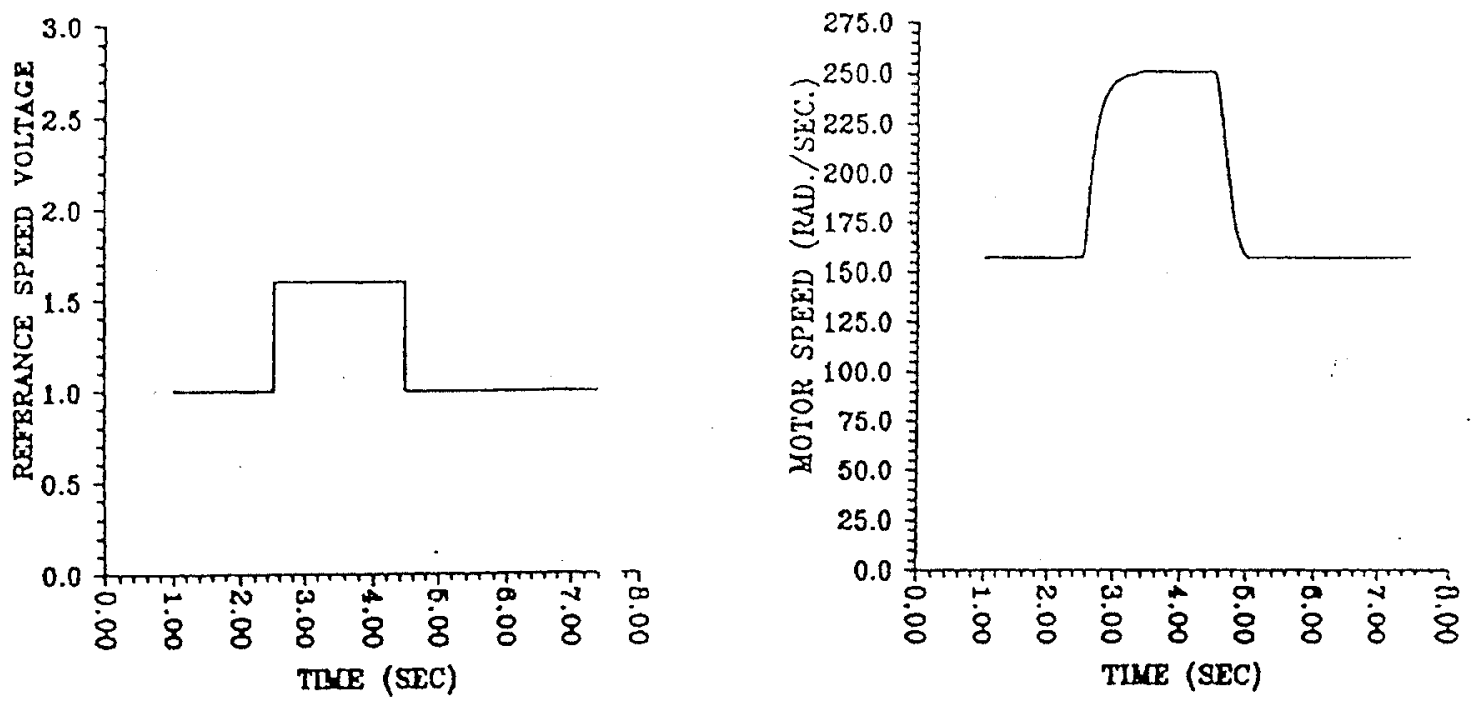

(a) simulation

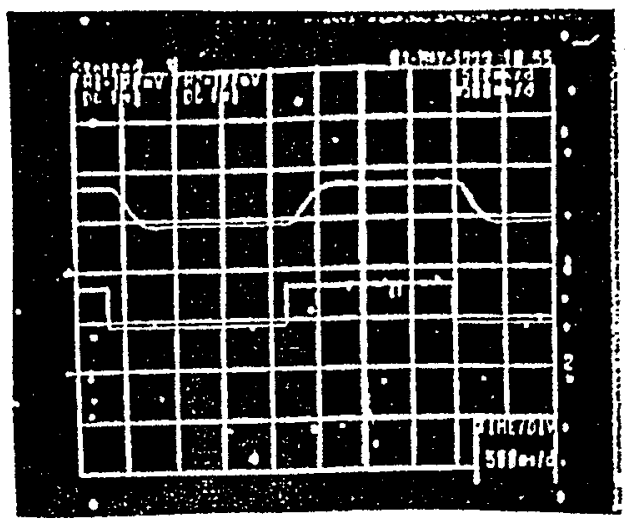

(b) Fiperimental

Figure (11): Variation of speed due to positive and negative step change of reference votlage for closed-loop system. 

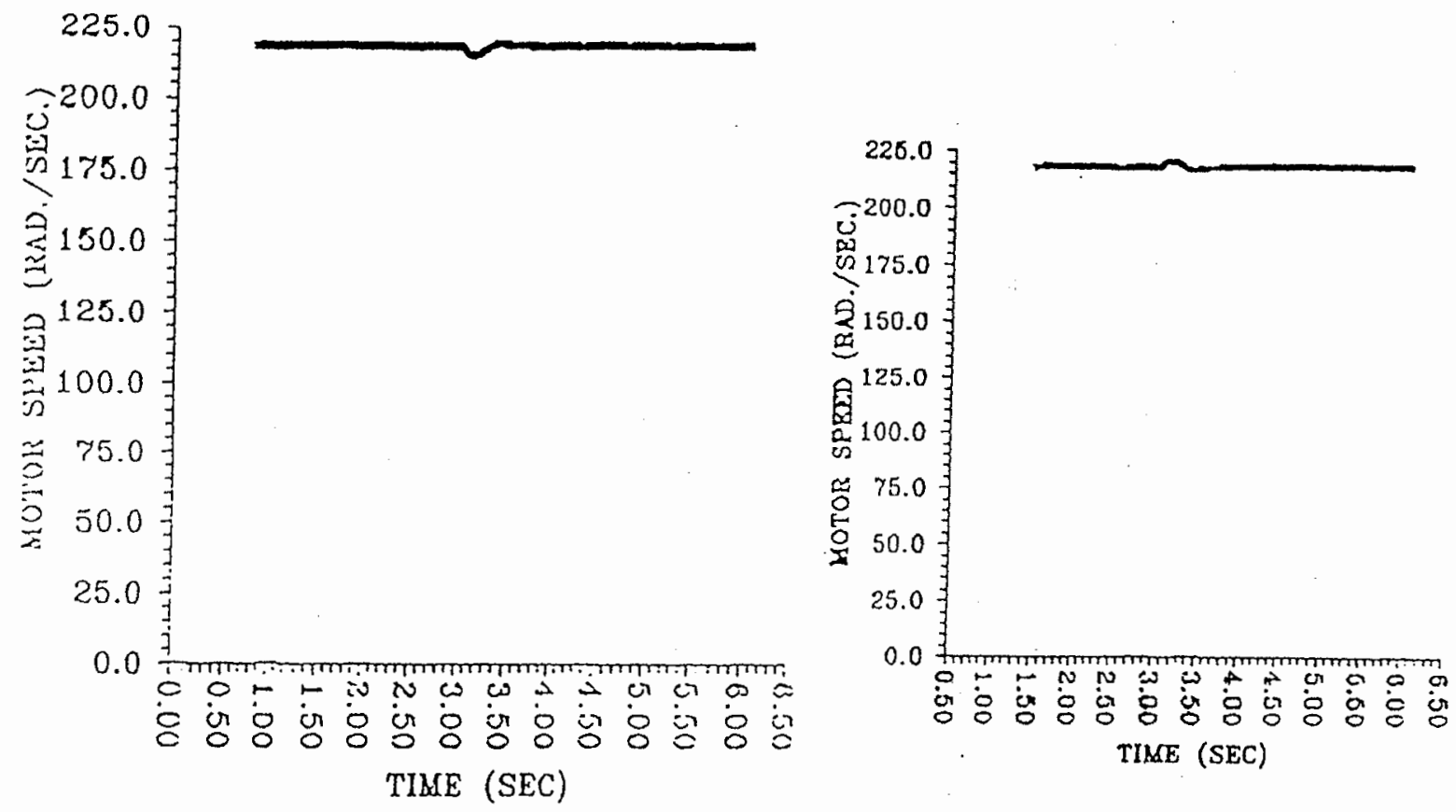

(a) simulation
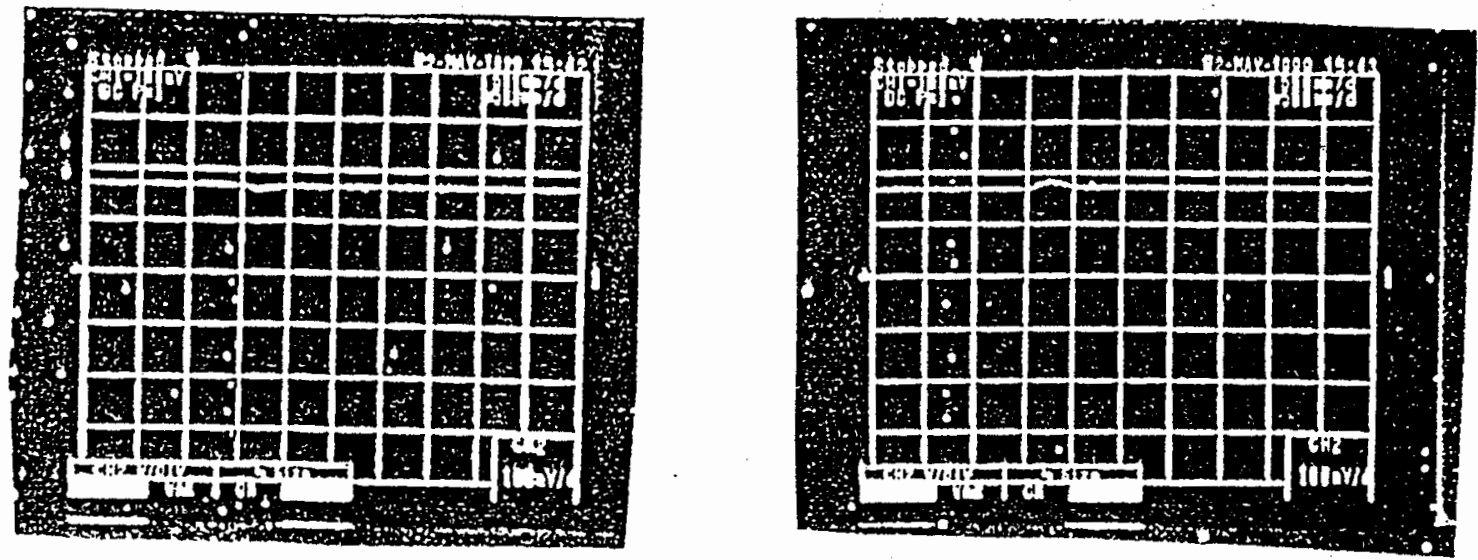

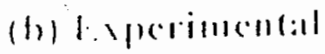

Figure (12): Variation of motor speed due to positive and negative change of load torque for closed loop system. 


\section{Appendix (3)}

The values of P.I. speed controller parameter are as follows:

$K=12, T_{e m}=0.09 \mathrm{Sec} ., K_{t}=0.019 \mathrm{Volt} /(\mathrm{rad} / \mathrm{sec}$.

$K_{1}=1.0 \quad, \quad \tau_{1}=0.09$ sec.

\section{REFERENCES}

[1] D.S.L. simonetti, J. Sebation and J. Uceda, "The discontinuous Conduction Mode Sepic and Cuk Power Factor Pre-Regulators: Analysis and Design", IEEE Trans. on Industrial Electronics, vol. 44, No.5, October, 1997, pp. 630-637.

[2] Kazerani, M., Ziogas, P.D. and Toos, G., "A Novel Active Current Waveshaping Technique for Solid-State Input Power Factor Conditioners", IEEE Trans. on Industrial Electronics, vol. 38, Feb. 1991, pp. 72-78.

[3] Prased, A.R., Ziogas, P.D. and Manias,S., "An Active Power Factor Correction Technique For Three-Phase Diode Rectifier", IEEE Trans. On Power Electronics, vol. 6, Jan, 1991, pp. 83-92.

[4] Lashine, A.E. and Saafan, F.A., "Analog Control of Cuk converter With High "Quality Performance", Engineering Research Bulletin, Monoufiya University, Faculty of Engineering, Vo. 19, No.1, 1996, pp. 17-33.

[5] Boys, J.T. and Green, A.W., "Current-Force Single-Phase Reversible Rectifiers", IEE proc. B (Electric Power Applications), vol. 136, Sept., 1989, pp. 205-211.

[6] Matinez, R. and Enjeti, P.N., "A High Performance Single-Phase Rectifier With Input Power Factor Correction", IEEE Trans. on. Power Electronics, Vol. 11, No. 2, March, 1996, pp. 311-317.

[7] Trakahashi, I. et al., "High Power Factor Correction Switching Regulator with no Rush Current", IEEE Trans. on Industry Applications, Jan. 1992, pp. 673-680.

[8] Itoh, R. and Ishizaka, K., "Single-Phase Setep-up / down Current Source Rectifier with Suppressed Resonance", IEE, Proc. B (Electric Power Applications), vol. 141, Jan. 1994, pp. 19-25. 
[9] Mchi, A. and Funabiki, S.; "Step-up/down voltage PWM AC-to-DC Converter with One Switching Device", IEE Proc. B. (Electric Power Applications), Vol. 140, Jan. 1993, pp. 35-43.

[10] Ghanem, M.C., Al-Haddad, K. and Roy, G., "A new Control Strategy to Achieve Sinusoidal Line Current in a Cascade BuckBoost converter", IEEE Trans. on Industrial Electronics, Vol. 43, June 1996, pp. 441-449.

[11] Brioschi, R.d. and Vieira, J.F., "High-Power-Factor Electronic Ballast with Constant DC-Link voltage", IEEE Trans. on Power Electronics, Vol. 13, No.6, Nov. 1998, pp. 1030-1037.

[12] Emauel, A.E. and Sen, K.K., "Steady-State Performance of the D.C. Motor supplied from Single-Phase Rectifier with Step-Up Converter A Unity Power Factor converter", IEEE Trans. on energy conversion, Vol.3, No.1, March 1988, pp. 172-178.

[13] Abdelhamid,T.H., "Three-Phase PWM DC Drive System With Active Input Power Factor Correction", Proceedings of Sixth Middle East Power Conference (MEPCON'98) Mansoura, Egypt, Dec. 1517, 1988, pp. 74-51.

[14] Shokralla, S.S., "A Simplified Approach For Closed-Loop Speed Control of a D.C. Motor Using AC-to-DC Converter", Alexandria Engineering Journal, vol. 36, No. 2, March, 1997, pp. B29-B41.

[15] Sen, P.C., "Thyristor DC Drive", John Wiley and sons Inc., New York, Book, 1981.

[16] Rashid, M.H., "P̈ower Electronics, Circuits, Devices, and Applications", Prentice-Hall International, Inc., 1988.

[17] Ned, Mohan, T.M., "Undeland, and W.P. Robbins, "Power Electronics: Converters, Applications and Design", John Wiley and Sons. Inc. New York, 1989. 
الألاء الديناميكى والمستقر بالزاوية المتماثلة للتحكم فى سرعة محرث تيار مستمر

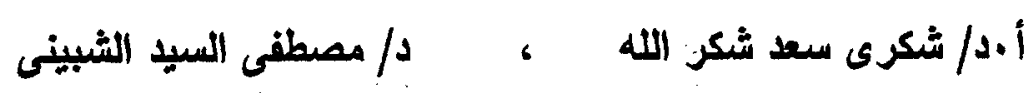

قسم الهندة الكهربية - كلية الهندسة بشبينة الكوم - جامعة المنوفيه

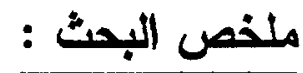

يقدم هذا البحت إقتراحسا للتمثيل العددى لمحرث تيّار مستمر منفمـل التذذيسة

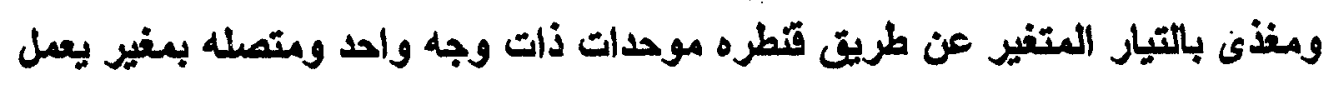

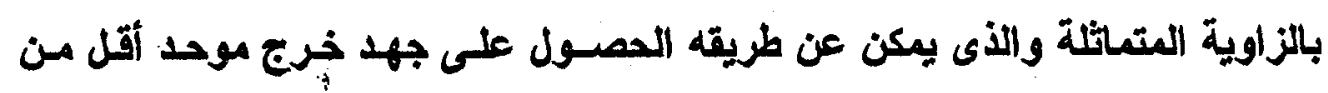

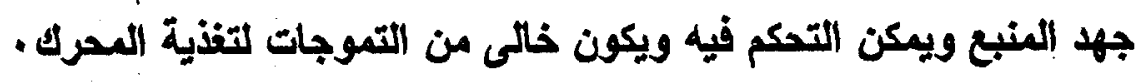

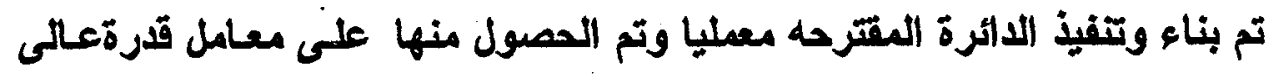
عن طريق إستخدام هذا النظام ، وقد بينت الدراسة أن التمثيل العددى يعتبر أداه

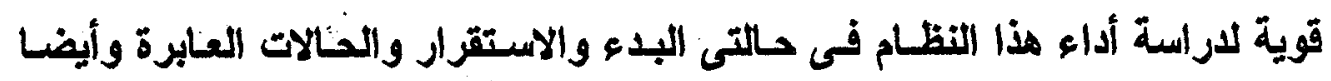

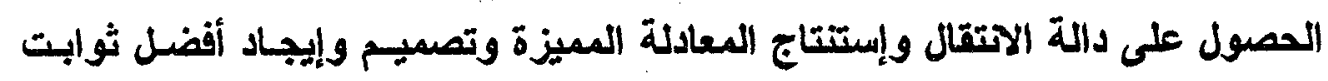

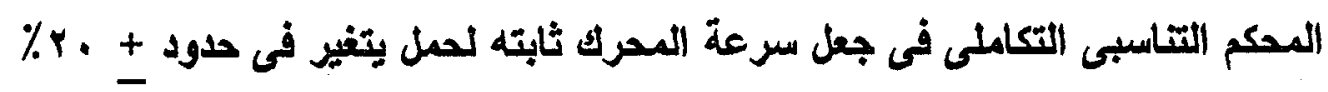

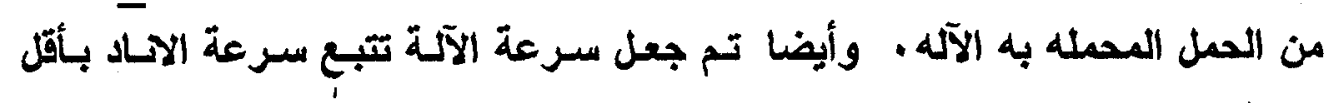

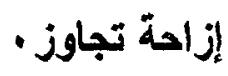

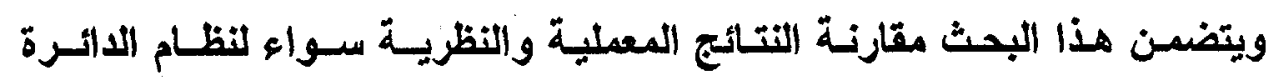

المفتوحة أو المغلقه وقد وجد تطابق كبير بينها مما يؤكد صحة لألاراسة النظرية. 